\title{
Building Pancasila Civilization in Industrial Era 4.0 for Millennial Generation
}

\author{
A. Aco Agus \\ Universitas Negeri Makassar \\ Email: andi.aco.agus@unm.ac.id
}

(Received: April 23-2020; revised: May 23-2020; published: June 30-2020)

\begin{abstract}
Pancasila as the basis and ideology of the Indonesian state is a set of values that become a way of life for the Indonesian state, this condition ensures that the foundation of the state and the practice of national and state life must be based on the values contained in the Pancasila. The main challenges in grounding Pancasila in this globalization era are; decreased intensity of understanding of Pancasila in society, social exclusivism related to the swift flow of globalization so that it leads to a stronger tendency for identity politicization and social fragmentation based on SARA, decreased morality of millennial generation caused by the flow of information and technology that is not filtered properly as a result of the current industrial era 4.0. The efforts made in facing challenges in the millennial generation are fostering the spirit of nationalism, planting and practicing the values of Pancasila and using the internet wisely, building ideas and future visions of a strong young generation based on Pancasila morality.
\end{abstract}

Keywords: Pancasila; State Ideology; Era 4.0; Millennials

\section{INTRODUCTION}

Pancasila, which can be called born from the many differences, should be a basic value that is always upheld by all Indonesian people (Muhaimin \& Fil, 2013; Siswoyo, 2013). But now there are many challenges (and also threats) that must be faced by Pancasila especially when in this era, Indonesian people are increasingly advancing in their civilization, especially in the use of technology. Technology basically was created to help humans in doing their tasks. Nevertheless, technology can also be a tool that can endanger human life if it is not used wisely (Ismail et al., 2016; Prasodjo, 2019; Sudarmi et al., 2019).

The 4.0 industrial revolution that is currently taking place has both positive and negative influences. The problem is whether Indonesian millennials are always able to get and utilize all positive influences and stem from all the negative effects of the industrial revolution 4.0. One positive impact of the 4.0 era is the ease of getting access to technology and information. The world including Indonesia entered the era of modernization, automation, digitalization, industrialization, use of technology, and the internet which will become the basis of activities in various sectors ranging from the social, cultural, educational, economic, and political sectors. The impact of the industrial revolution 4.0 also had an influence that touched all areas such as the lifestyle of the Indonesian people to Pancasila as the state ideology.

Pancasila is the ideology of the nation which is expected to be a spirit for every life pulse of the community and constitutional activities and in social life, because Pancasila is seen as an acculturation medium of various thoughts about religion, education, culture, politics, social, and even economy (Andrew et al., 2019; Juneman et al., 2012). So that the hustle and bustle and 
196 Jurnal Ilmiah Ilmu Administrasi Publik: Jurnal Pemikiran dan Penelitian Administrasi Publik

Volume 10 Number 1, January - June 2020. Page 195-202

challenges of the swiftness of information technology can be filtered by the actualization of the values of the Pancasila which is absorbed in the souls of every Indonesian people, especially millennials who will be the determinants of the future of Indonesia (Nasrullah, 2016).

\section{Pancasila Ideology in the Era of Millennial Generation}

To survive, this era must belong to the Indonesian millennial generation. They will answer the challenges of the world of the future with the values of the nationalist and religious community. From an economic perspective the government has anticipated technological progress marked by the 4th industrial revolution through increased economic growth with the use of digital as the main production factor.

Economic stagnation 4 to 6 years ago, can now be driven better. To illustrate the digital power of community productivity, the government plans to maximize elective throughout the country. However, what needs to be stressed is that no matter how swift the industrial era 4.0 millennial generation must not change the foundation of the Pancasila State (Andrew et al., 2019; Juneman et al., 2012; Sitorus, 2016; Sudaryanti et al., 2015).

We must continue to spur national development by remaining based on Pancasila. The importance of maintaining noble values of interfaith religious relations that are harmonious and complementary. Lndonesia is also supported by a spirit that grows from the values of Pancasila in the face of technological and economic developments in the future, it is necessary to maintain good and productive communication between religious people who uphold Pancasila values. One of the keywords is the generation that built the Pancasila civilization.

Siswomihardjo (2001) concerning the reflection of the Pancasila on the question of nationality and contemporary problems suggests that the revitalization of Pancasila as the basis of the State means that we must place the Pancasila in its integrity by opening and exploring it as a paradigm in the dimensions attached to it, namely:

The reality dimension is in the sense that the values contained in are practically conconfirmed in daily life, the idealization dimension in the sense that the ideals contained therein are not merely hats without meaning, but objectified to arouse and optimism in people's view of life in order to prospectively see the future., bivitas intensified in the sense of being open and able to follow the dynamics of the times"

Radicalization of Pancasila, Darmaputera (1988) operationally offers five steps that must be taken by the Indonesian people towards Pancasila, namely: 1) returning Pancasila as a state ideology, 2) developing Pancasila as an ideology into Pancasila as a science, 3) seeking Pancasila to have consistency with legislation products, kaherensi between precepts and correspondence with social reality, 4) Pancasila which initially only serves the interests of the vertical (State) becomes Pancasila which serves the interests of horizontal and 5) makes Pancasila as a criticism of state policy.

While the Chairman of the Indonesian People's Consultative Assembly (MPR) Bambang Soesatyo mentioned the five main challenges in the grounding of Pancasila in the current era of globalization, with regard to these challenges, young people must be at the forefront in implementing the values of Pancasila, the challenges in grounding Pancasila in the current era of globalization. namely: 1) understanding of Pancasila, currently the community is 
experiencing a decrease in the intensity of Pancasila learning and also a lack of effectiveness and attractiveness of Pancasila learning, 2) Social exclusivism related to the swift current of globalization so that it leads to the strengthening of the tendency of identity politicization and the strengthening of symptoms of polarization and social fraqmentation based on SARA, 3) still wide social inequality, because there is still a centralization of economic development in certain regions, in addition, the widening social gap between economic actors and economic policies that prioritize the extractive sector that is less developed the added value, 4) the development of Pancasila where the weak institutionalization of Pancasila values in political, economic and cultural developments as well as the weak insight of Pancasila ideology in the obstacle of State administrators, 5) the exemplary of Pancasila. In context, the challenge faced is still the lack of example of government and community leaders.

Besides that, the era of globalization has given challenges to Pancasila values, namely: 1) nationalism and internationalism, this change is the value and attitude of globalization nationalism has made the spirit down, because everyone is trying to maximize their satisfaction and can live in any country based on their competence and commitment 2) western culture and Indonesian culture (westremisasi), 3) the need for a second reform as the restoration / reactualization of the Pancasila.

Handayani \& Winarno (2016) suggests the implementation of Pancasila in State policies, namely: 1) Cultivating Pancasila in the life of the nation and state in the aspect of political life is civilizing democracy based on the four precepts of Pancasila. The state, in this case the government, should not release the burden of responsibility by only providing assistance and support to the legislative body, and the judiciary to popularize Pancasila, 2) civilizing Pancasila in aspects of economic life, namely conducting a study of discussion and dialogue on the Pancasila economy, 3) civilizing Pancasila in the aspect of socio-cultural life as a paradigm of socio-cultural development in the direction of socio-cultural development in lndonesia, 4) civilizing Pancasila in the aspects of defense and security life as a paradigm of developing national security is a right and obligation of every citizen, developing the principle of living side by side in peace with other countries.

The weakness of the Pancasila earth is due to our inability to actualize Pancasila both as a philosophy and a nation's way of life. Upgrading and socialization of Pancasila so far has stopped as memorization points. The severity of various Pancasila discourse in the knowledge environment in the knowledge environment fails to be our culture as a life stand in the axiology of nationality and state, both in the framework of the formulation of laws and state policies as well as in the conduct of organizers and citizens, consequently Pancasila seems neglected to be poor in theory, there is no integrity between speech and action.

Pancasila as an ideology of the State of Indonesia should become the basis of thought in seeing and responding to various changes and problems that occur. Because Pancasila must be continuously presented as a public discourse (public discounse) so that it can always be studied, elaborated, and then internalized into people's lives so that it finds its context and relevance to the pattern of life in various plural localities as judicial views (2015). social holistic and anticipatory. Based on the Pancasila view of life, changes in the social system are a function of changes in the mental cultural domain (1st, 2nd, 3rd, 3) political realms (4th sila) and material realms (5th sila). 
198 Jurnal Ilmiah Ilmu Administrasi Publik: Jurnal Pemikiran dan Penelitian Administrasi Publik

Volume 10 Number 1, January - June 2020. Page 195-202

\section{Challenges in Millennial Generation}

The Millennial Era is an era laden with significant changes in all aspects of life, related to the development of technology and digital communication tools, followed by a pragmatic perspective and attitude (Calvert, 2004; Dijkink, 2009). Millennial generation is a generation who is very proficient in technology, with its capabilities in the world of technology and existing facilities, this generation has many opportunities to be far ahead of the previous generation, millennial generation has unique characteristics based on region and socio-economy. One of the main characteristics of millennial generation is marked by increased use and familiarity with communication, media and digital technology. Raised by technological advancements, millennials have the following characteristics: 1) creative, 2) informative, 3) passionate and productive, 4) this generation grows into open minded individuals, 5) upholds freedom, 6) critical and brave, 7) must have a social account as a communication tool and information center, 8) interest in reading conventionally has decreased, 9) prefers cellphones over television, 10) makes Google search as a family, 11) believes in personal contentism rather than one-way information (Mochinad Krisnariyansah: 2018).

Rhenald Kasali Professor of the Faculty of Economics and Business, University of Indonesia stated nine important points about Millennial Mindset, namely: 1) Quick Response, 2) Realtime, 3) Followup, 4) Finding the Way, 5) Sniffing information and truth, 7) Information technology support, 8) 24/7 not eight fo five, 9) connected.

The challenges facing millennial generation are:

1. The influence of globalization, the influence of globalization that can change the mind set or someone, society or citizens who are easy and willing to be controlled by other countries is one of the negative impacts of the globalization.

2. Life of political ethics that is in harmony with the life of Pancasila. The lack of exemplary political ethics of the nation and the display of conflicts between institutions are a bad example in the life of the nation and state.

3. Declining morality and moral awareness. The low obedience and moral awareness to make Pancasila as a guideline of life in the nation and state.

4. The values of Pancasila do not seem to be grounded, they have not been well practiced by the Indonesian people. Pancasila seems to only be a symbol, without actually being implemented both at the level of state life and at the level of community life.

5. The lives of Indonesian people, especially the younger generation in the era of globalization, have had a very strong influence from outside cultural values, so that many attitudes and behaviors that are not in line with the values of Pancasila have begun.

6. The values of nationalism are also seen by some as experiencing erosion at this time, especially among the younger generation.

7. The development of the understanding of security that does not consider the importance of nationalism and the nation-state of Indonesia and views universalism more important.

8. The role of education still needs to be questioned in both formal and non-formal education pathways in internalizing the values of Pancasila, including the values of nationalism to the Indonesian people, especially to the younger generation.

Efforts made in facing challenges in millennial generation: 
1. Cultivating the spirit of nationalism, which is strong for example the spirit of chanting domestic products.

2. Embed and practice the values of Pancasila as well as possible.

3. Implanting and implementing religious teachings as well as possible.

4. The need for attention from parents in the association and way of life of their children.

5. Selective on the effects of globalization in the political, economic ideology, socio-cultural aspects of the nation.

6. Using the internet and social media wisely, it cannot be denied that the development of technology and the internet can bring both positive and negative impacts on young people.

7. Be open to new experiences, in an increasingly dynamic and modern world like this, it is demanded to be more creative, innovative and participate in various activities that are beneficial to us such as joining social organizations, volunteering for poor people or participating in events, competition events . These activities will train ourselves to be able to think more creatively and move more actively.

8. Building ideas and visions going forward, developing creative ideas in their minds we can start with simple ideas. Who knows from this simple idea, we can actually form a new startup that can solve the problems that are around us and provide new jobs for the community.

In this era everything moves quickly, the world becomes without limits, information can be obtained anywhere and from anyone. Today's generation must try and be able to be wise, especially in the use of social media, we can be useful and get smarter when using social media properly.

Observing the dynamics of contemporary nationalities, the Indonesian people should reflect significantly on the value of Indonesian inclusive significantly by saying revitalizing Pancasila in an increasingly complex life, surrounded by the influence of the development of modernist technology, which always threatens our nationality. So naturally Pancasila is a national guideline. Because caring for the idea of Pancasila in a civilization is a shared duty and responsibility that must be implemented.

\section{CONCLUSION}

The role of Pancasila is very important in dealing with the current of globalization, because Pancasila is the power of ideas rooted in the earth of Indonesia, for this reason it is necessary to instill the values of Pancasila in the life of the nation and state society by maintaining consistency, relevance and contextualism. In this era everything moves quickly, the world becomes borderless, information can be obtained anywhere and from whoever the current generation must try and be able to be wise, especially in the use of social media, they easily get information from outside through the internet that is sometimes the information is not in accordance with the values of Pancasila. This can be overcome by utilizing the development of information as well as Science and Technology (IPTEK) and Faith and Taqwa (IMTAK) as a media in the planting and strengthening of Pancasila in the era of the millennial generation industrial revolution in grounding Pancasila which can be started from personal, family, colonize other people to contribute in earthing, internalizing, instilling the value of Pancasila as 
200 Jurnal Ilmiah Ilmu Administrasi Publik: Jurnal Pemikiran dan Penelitian Administrasi Publik Volume 1o Number 1, January - June 2020. Page 195-202

the next generation of our nation can filter information that is not appropriate to be imitated. Therefore implementing the values of Pancasila in a civilization is our duty and responsibility.

\section{REFERENCES}

Andrew, J., Henry, S., Yudhisthira, A. N., Arifin, Y., \& Permai, S. D. (2019). Analyzing the Factors that Influence Learning Experience through Game Based Learning using Visual Novel Game for Learning Pancasila. Procedia Computer Science, 157, 353-359. https://doi.org/https://doi.org/10.1016/j.procs.2019.08.177

Calvert, J. (2004). The Mythic Foundations of Radical Islam. Orbis, 48(1), 29-41. https://doi.org/https://doi.org/10.1016/j.orbis.2003.10.014

Darmaputera, E. (1988). Pancasila and the search for identity and modernity in Indonesian society: A cultural and ethical analysis. Brill.

Dijkink, G. (2009). Geopolitics and Religion (R. Kitchin \& N. B. T.-I. E. of H. G. Thrift (eds.); pp. 453-457). Elsevier. https://doi.org/https://doi.org/10.1016/B978-008044910-4.00778-1

Handayani, I., \& Winarno, D. W. (2016). Pancasila Sumber Nilai Keberagaman Beragama Bangsa Indonesia. Jurnal Seminar Nasional Hukum, 3.

Ismail, A., Sulur, A. H., Akib, H., \& Salam, R. (2016). Snapshot of Society Social-Economic Welfare based on Human Development Index in Polewali Mandar Regency, Indonesia. International Conference on Public Organization VI (ICONPO VI), 847-858.

Juneman, Meinarno, E. A., \& Rahardjo, W. (2012). Symbolic Meaning of Money, Self-esteem, and Identification with Pancasila Values. Procedia - Social and Behavioral Sciences, 65, 106-115. https://doi.org/https://doi.org/10.1016/j.sbspro.2012.11.099

Muhaimin, H., \& Fil, S. (2013). Indonesia now. Between Pancasila and crisis of democracy in Indonesia. International Journal for Public Management and Politic Development, 1(1), $23-37$.

Nasrullah, M. (2016). Implementasi Sistem Informasi Manajemen Berbasis Teknologi Informasi Di Universitas Negeri Makassar. Jurnal Ilmiah Ilmu Administrasi Publik, 5(2), 53-63.

Prasodjo, T. (2019). Knowledge Management: Sustainable Human Resource Development in Public Sector Organizations. Jurnal Ad'ministrare, 6(2), 159-166.

Siswomihardjo, K. W. (2001). Ilmu Pengetahuan: Sebuah Sketsa Umum mengenai Kelahiran dan Perkembangannya sebagai Pengantar untuk Memahami Filsafat Ilmu. Disajikan Pada Internship Filsafat Ilmu Pengetahuan Universitas Gajah Mada, Yogyakarta, Tanggal, 2-8.

Siswoyo, D. (2013). Philosophy of education in Indonesia: Theory and thoughts of institutionalized state (PANCASILA). Asian Social Science, 9(12), 136.

Sitorus, J. H. E. (2016). Pancasila-based Social Responsibility Accounting. Procedia - Social 
$\begin{array}{llll}\text { and } \quad \text { Behavioral } & \text { Sciences, }\end{array}$ https://doi.org/https://doi.org/10.1016/j.sbspro.2016.05.054

Sudarmi, S., Sunusi, S., \& Syam, A. (2019). Development of human resources In the perspective of the career development of teachers at the State Vocational School in Makassar City. Jurnal Ad'ministrare, 6(1), 45-50.

Sudaryanti, D., Sukoharsono, E. G., Baridwan, Z., \& Mulawarman, A. D. (2015). Critical Analysis on Accounting Information Based On Pancasila Value. Procedia - Social and Behavioral Sciences, 172 , 533-539. https://doi.org/https://doi.org/10.1016/j.sbspro.2015.01.399 
202 Jurnal Ilmiah Ilmu Administrasi Publik: Jurnal Pemikiran dan Penelitian Administrasi Publik Volume 1o Number 1, January - June 2020. Page 195-202 